\title{
Filosofia e eSPIRITUALIDAde EM SimONe WeIL À LUZ dA MISÉRIA HUMANA
}

\author{
[Philosophy and Spirituality in Simone Weil in the light of Human Misery]
}

Resumo: O objetivo deste artigo é proporcionar uma reflexão sobre filosofia e espiritualidade à luz da miséria humana em Simone Weil. Para tanto, apresenta-se, inicialmente, a ideia de força a partir da leitura weiliana da Ilíada e, posteriormente, se faz uma análise do conceito de infelicidade (malheur) a partir do livro Attende Dieu. Por fim, retoma-se algumas ideias expostas nas considerações iniciais, procurando pensar um pouco sobre a vocação intelectual que a filósofa francesa afirma possuir, recuperando este tema no cruzamento dos conceitos de força e infelicidade, refletindo a união da filosofia com a espiritualidade para uma melhor compreensão da miséria humana.

Palavras-chaVe: Filosofia; Espiritualidade; Miséria humana; Simone Weil

\begin{abstract}
In this article, we want to reflect on philosophy and spirituality in the light of human misery in Simone Weil. For this, first, we present the idea of strength from the Weil's interpretation of the Iliad and next we analyze the concept of unhappiness (malheur) contained in the book Waiting for God. Finally, we return to some ideas exposed in the initial considerations, trying to think a bit about the idea of intellectual vocation that the French philosopher presents, resuming this idea at the intersection of the concepts of strength and unhappiness with the union of philosophy and spirituality for a better understanding of human misery.
\end{abstract}

KeYwORDs: Philosophy; Spirituality; Human misery; Simone Weil

Ser criaturas não é necessariamente ser infeliz, mas é necessariamente ser exposto à infelicidade.

S.W.

\section{CONSIDERAÇÕES INICIAIS}

Densar as relações entre filosofia e espiritualidade à luz dos escritos de Simone Weil (1909-1943) implica levar em consideração algumas peculiaridades do pensamento weiliano e, naturalmente, fazer recortes que espelham opções de possíveis interpretações. Significa, também, percorrer as ideias de uma escritora profunda, cujo pensar transita entre o agnosticismo, a filosofia praticada com a mais fina inteligência e com todos os sentidos, a crítica à igreja enquanto coisa social, a acolhida das mais diversas tradições religiosas, passando pela consciência da sua vocação intelectual até a

* Doutora em Filosofia pela Universidade de Coimbra. Professora Associada do Curso de Filosofia e Professora Colaboradora do Programa de Pós-graduação em Literatura e Interculturalidade (PPGLI) da UEPB.E-mail: mar.simonem@gmail.com 
mística da compaixão capaz de enxergar os invisíveis (miseráveis) do mundo. Numa carta data de 26 de maio de 1942, dirigida ao seu amigo, Padre Perrin ${ }^{1}$, ela escreve:

Pode igualmente acreditar na minha palavra de que a Grécia, o Egito, a Índia antiga, a China antiga, a beleza do mundo, os reflexos puros e autênticos desta beleza nas artes e na ciência, o espetáculo dos recônditos do coração humano em corações despidos de crença religiosa, todas estas coisas fizeram tanto quanto as coisas visivelmente cristãs para me entregar cativa a Cristo. Creio poder dizer mais. Que o amor a estas coisas, que se encontram fora do cristianismo visível, me mantém fora da igreja. Um tal destino espiritual deve parecer-lhe ininteligivel. Mas precisamente por esta razão é adequado como objeto de reflexão. É bom refletir no que força à saída de si mesmo. (WEIL, AD, 2005, p. 87 , itálicos nossos) $)^{2}$.

No trecho acima, dentre outras coisas, Simone Weil faz referência a uma das razões que a motiva a permanecer fora da igreja católica, ou seja, sem se batizar. Esta razão diz respeito à forma como ela lê outras culturas e como encontra nessas, mesmo nas despidas de crenças religiosas, motivos que a fizeram se entregar a Cristo. Mas gostaríamos de frisar nessas considerações iniciais o final da citação que colocamos em destaque. Primeiro ela chama a atenção de Perrin para dizer que o que nós podemos chamar de sincretismo religioso seria algo difícil para ele compreender. Depois, exatamente por isso, ou seja, por parecer ininteligível, é adequado como objeto do pensamento porque força à saída de si mesmo. Ora, o que é a filosofia senão o abalo das nossas certezas. E o que é o abalar das certezas senão a saída de si, da nossa zona de conforto. Desta forma, a pensadora francesa traz o tema da espiritualidade para o âmbito da filosofia, ou melhor, nos mostra que a espiritualidade é um tema que faz parte das discussões filosóficas, sendo uma dimensão humana importante que põe em movimento a nossa inteligência.

Ela nos provoca esse exercício de movimento também quando nos apresenta a sua leitura da Ilíada de Homero, ou seja, não a lê como normalmente se concebe a noção de epopeia, isto é, um gênero literário que mostra os feitos de um grande herói, neste caso de Aquiles ${ }^{3}$. Pelo contrário, a grande personagem da epopeia homérica é a força que a todos destrói: gregos e troianos, vencedores e vencidos. Assim, lendo o passado, reflete sobre o seu presente (a segunda guerra mundial), unindo, numa mesma chave de leitura, literatura, filosofia e espiritualidade, como esperamos mostrar mais adiante. Antes disso, apresentemos, ainda que resumidamente, a filósofa em apreço.

Simone Weil Nasce em Paris em 3 de fevereiro de 1909, numa família burguesa de judeus não praticantes e como ela mesma diz em uma das suas cartas, foi criada num completo agnosticismo. Seu pai era médico e sua mãe dona de casa, ambos se responsabilizaram pela educação inicial dos filhos devido aos anos instáveis da primeira guerra mundial. Simone tinha um irmão, André, que se tornou um matemático eminente. $\mathrm{Na}$ juventude ela entra para o Liceu Henri IV e estuda com o famoso professor e filósofo Alain (Émile Chartier), que desenvolveu um papel importante e determinante na forma como ela fazia filosofia.

Talvez em nenhuma outra pensadora a vida e a filosofia se relacionem tão estreitamente e de forma tão coerente, pois Simone Weil escreve aquilo que vive e cobra esta mesma coerência daqueles que escrevem. Na sua busca incessante pelo que ela chama de verdade, acaba se deparando com a tirania daqueles que sabem e, desta forma, percebe que só o uso da razão no gabinete de trabalho não é suficiente para entender, por exemplo, as causas da opressão operária e decide, por isso mesmo, fazer experiências concretas, como relata PERRIN (2005, p.28): "Leituras e escrita não preenchiam a sua vida; o gosto do seu espírito e a vontade de compaixão que a caracterizaram não a podiam deixar alheia à vida dos mais infelizes; procurava-os e misturava-se com eles para os conhecer e ajudar". Daí encontrarmos esta personagem 
multifacetada: professora de filosofia; militante de esquerda; sindicalista; anarquista; pacifista; operária; mística; amante dos gregos; interessada nas mais diferentes religiões e culturas.

Da doçura e da preocupação com a família, que está em Nova York fugindo do nazismo, ao trabalho na escola como professora e também na fábrica como operária, passando pela crítica ao marxismo e aos partidos políticos, isso para não falar do seu interesse pela matemática e pelas ciências, a paixão pelos gregos antigos, a redação de poemas e tragédias, as leituras da literatura hindu e budista (e também dos mitos e do folclore de culturas diferentes da sua) até a experiência mística (não esqueçamos das duras críticas que fez à igreja católica), e a forma intempestiva com que tratava alguns dos seus contemporâneos, tudo isso constitui, com todas as suas contradições, a filósofa Simone Weil. Além disso, e apesar da "suposta arrogância" com que foi tratada, Simone de Beauvoir reconhece em Weil um coração capaz de bater através do universo inteiro (BEAUVOIR, 2009, p. 182) ${ }^{4}$.

Dito isto, chamamos atenção ainda, como escreve Puente (2013, p. 35) que: "Através da reabilitação dos mitos e símbolos gregos, Simone Weil visava formular as bases para a instauração de uma verdadeira espiritualidade em uma época profundamente marcada pelos chamados pensadores da suspeita, ou seja, Nietzsche, Marx e Freud". Ora, num período marcado pela crítica à religião e em que quase tudo que possa estar ligado ao espiritual é lido na sua relação com a superstição e, portanto, destituído de razão, a filósofa francesa ousa afirmar sua espiritualidade dizendo que "A fé é a experiência de que a inteligência é iluminada pelo amor" e, numa construção ainda mais desconcertante para os que acham que a razão dá conta de tudo ou para os que pensam que apenas o que é captado pela inteligência ou pelos sentidos é real, ela escreve: "Sabemos por meio da inteligência que aquilo que a inteligência não apreende é mais real que aquilo que ela apreende" (WEIL, $P G, 1993$, p. 141) ${ }^{5}$.

Do exposto, nossa proposta para este artigo é refletir um pouco sobre filosofia e espiritualidade à luz dos últimos escritos (última fase) de Simone Weil. Em geral seus escritos podem ser divididos em duas fases, a primeira inclui um pensamento mais social e político e a segunda, um pensamento mais filosófico e religioso. Mesmo assim, essas duas fases não devem ser vistas como antagônicas ou como se existissem duas "Weil", afinal, num colóquio realizado na Sorbonne em maio de 1999, cujo título foi "Simone Weil: espiritual ou política", apresentou-se nas discussões realizadas no próprio colóquio essa dicotomia como um falso dilema, pois, conforme Silva (2009, p.7), a mística iluminava seu engajamento político e a política transportava para a mística a densidade do sofrimento humano. Vejamos, então, para começar, um pouco deste sofrimento humano à luz da sua leitura da Ilíada.

\section{A LEITURA da ILÍADA: A FORÇA COMO ESPELHO DA MISÉRIA HUMANA}

A filosofia de Simone Weil, embora enraizada na sua época ${ }^{6}$, não deixa de ser iluminada por diferentes culturas e tradições, como é o caso da Grécia clássica. Deste modo, e para não perdermos de vista a forma como faz da filosofia um modo de vida e deste, como veremos, um exercício espiritual (Cf., ESTELRICH, 2009, p. 39-57), iniciemos esta parte sobre a Ilíada com uma citação sobre Antígona:

Cerca de dois mil e quinhentos anos atrás eram escritos na Grécia poemas muitos belos. Hoje, eles não são mais lidos, a não ser pelos especialistas nesse estudo, o que é uma grande pena. Pois esses velhos poemas são de tal forma humanos que ainda estão muito próximos de nós e podem interessar a toda gente. Seriam até muito mais comoventes para o comum dos homens, ou seja, para aqueles que sabem o que é lutar e sofrer, muito mais do que para os que passaram a vida entre as quatro paredes de uma biblioteca" (WEIL, $S G, 1996$, p.373) ${ }^{7}$. 
O texto foi publicado, pela primeira vez, numa revista de operárias da cidade de Rosières, na França, em 1936 e posteriormente republicado em La Source Grecque. Para além da paixão que sentia pelas tragédias gregas, a filósofa francesa acreditava que se tratavam de textos tão humanos que poderiam (co)mover qualquer pessoa. Certa disso, ela escreve, entre abril e maio de 1936, uma carta a um engenheiro diretor de 150 uma fábrica, falando-lhe de um antigo projeto que tem de tornar os clássicos da poesia grega, que afirma amar com paixão, acessíveis às pessoas mais simples e acrescenta: "No ano passado senti que a grande poesia grega estaria cem vezes mais perto do povo, se ele a pudesse conhecer, [...]" e reitera, cheia de orgulho, que se suas matérias sobre o tema forem lidas para os operários, até os iletrados saberão mais sobre esta literatura do que a maioria dos bacharéis. Para ela: "Homero e Sófocles estão cheios de coisas pungentes e profundamente humanas, é só exprimi-los e representá-los de forma que se tornem acessíveis a todos" (WEIL, CO, 1996, p. 371 e 372 respectivamente) ${ }^{8}$. Como assevera a interpretação de Puente, Simone Weil escreveu textos para operários em que descreve, de modo simples e sem vulgarização, o conteúdo de algumas tragédias. Tratase para ele, não de confrontação (entre passado e presente), mas de uma chave de leitura. Nas suas palavras, a filósofa parisiense "[...] quer ler, isto é, decodificar, e interpretar os acontecimentos presentes à luz dos acontecimentos passados, sem deixar de ver, contudo, [...] as características próprias de uma dada situação presente" (PUENTE, 2013, p. 69). Passemos agora a Homero.

A Ilíada ou o poema da força é um texto escrito por Simone Weil três anos antes da sua morte. Foi publicado em 1940, durante a invasão alemã a Paris, e faz parte, assim como Antígona, de la Source Grecque, obra compilada entre 1939 e 1943 que contém textos em que a filósofa francesa retoma a leitura dos gregos, como as tragédias, Platão, Heráclito, os pitagóricos e repensa, a partir do passado, o presente, na tentativa de lançar alguma luz sobre o futuro. Na sua leitura da Ilíada destaca-se a ideia da força como sendo central na poesia de Homero. A força que iguala vencedores e vencidos e consequentemente oprime a todos que a ela estão submetidos ou porque mata, na sua expressão mais sumária, ou porque transforma o homem em pedra ou em coisa, na sua expressão mais sutil. Assim, fazendo uma leitura bem peculiar da epopeia homérica, Simone Weil nos põe diante da força e das mortes dela derivadas, oferecendo-nos um quadro pungente da existência humana em que nenhuma ideia de imortalidade pode nos servir de consolo ${ }^{9}$. Deste modo, para ela, a ideia central da Ilíada não é a ira de Aquiles e tudo o que daí deriva (como a imortalidade do guerreiro), mas a ideia da força ${ }^{10}$ que maneja os homens, transformando todos em infelizes. Os infelizes, aliás, sempre fizeram parte da reflexão filosófica weiliana. Aqui eles também comparecem à luz da poesia homérica e fazem-nos pensar a miséria humana.

Deste modo, Simone Weil começa o seu texto da seguinte forma: "O verdadeiro herói, o verdadeiro assunto, o centro da Ilíada, é a força. A força que é manejada pelos homens, a força que submete os homens, a força diante da qual a carne dos homens se contrai" (WEIL, CO, 1996, p.379). Apresenta, deste modo, uma interpretação bastante peculiar da Ilíada, mostrando a alma humana na sua relação com a força, ora sendo arrastada e, portanto, padecendo por causa dela, ora obcecada com tal ideia, julgando dominá-la. No entanto, como afirma no mesmo texto, "A força é aquilo que transforma quem quer que lhe seja submetido em uma coisa" (WEIL, CO, 1996, p.379). Logo, na leitura weiliana da epopeia homérica, o herói é apenas uma coisa arrastada pela poeira, não há por trás disso nenhuma bela morte, nenhum poema reconfortante, nenhuma imortalidade consoladora. O que há é somente morte, e em meio a uma série de citações da Ilíada que a própria pensadora francesa traduz ${ }^{11}$, ela escreve, depois de citar uma passagem em que Andrômaca prepara um banho para Heitor: "Quase toda a Ilíada se passa longe dos banhos quentes. Quase toda a vida humana se passou sempre longe dos banhos quentes" (WEIL, CO, 1996, p. 380). Reitera, assim, a miséria humana e a frequência que a aproxima da imagem da dor e a afasta da imagem dos banhos quentes, lembrando, por este afastamento, a morte, e traçando um paralelo entre o passado e o 
presente.

Começa, deste modo, a relacionar força e morte, refletindo sobre as diferentes forças e, consequentemente, sobre as diferentes mortes. Lemos: "A força que mata é uma forma sumária, grosseira, de força. Quanto mais variada em seus processos, quanto mais surpreendente em seus efeitos é a outra força, a que não mata; isto é, a que não mata ainda" (WEIL, CO, 1996, p. 380). Para a primeira força, a sumária, expõe o combate entre Aquiles e Heitor. Aquiles, o maior guerreiro grego mata Heitor, o maior guerreiro troiano; mas ele, Aquiles, sabe também que a sua morte é iminente. Já em relação à segunda força, a que não mata, Simone Weil cita várias cenas de Aquiles e Agamêmnon.

Aquiles, o herói orgulhoso, chora, no início da Ilíada, porque Agamêmnon lhe tira sua prenda de guerra, Briseida. Na leitura Weiliana, "Agamêmnon humilhou Aquiles deliberadamente, para mostrar que o senhor era ele". Mas, pouco depois, é Agamêmnon que é obrigado a se rebaixar, a suplicar pela volta de Aquiles e a entregar a sua prenda de guerra, Criseida. Assim, oscilando entre vários personagens da epopeia homérica, a pensadora francesa nos faz refletir que "com a mesma dureza com que a força esmaga os vencidos, embriaga aquele que a possui, ou julga possuí-la". Porém, o que ocorre, como ela conclui, é que "ninguém de fato a possui verdadeiramente" (WEIL, CO, 1996, p. 387 e 386).

Ainda em relação à força que não mata, a filósofa contemporânea acrescenta: "seja como for, ela transforma o homem em pedra. Do poder de transformar um homem em coisa fazendo-o morrer procede um outro poder [...], o de transformar em coisa um homem que continua vivo" (WEIL, CO, 1996, p.380 -381). A reflexão está focada agora na ideia de como um ser vivo, que tem uma alma, pode ser uma coisa. Pensa ela ser este um estado estranho para a alma, daí se perguntar: "Quem dirá quanto lhe custa, a cada momento, conformar-se, torcer-se, dobrar-se sobre si mesma?" E a resposta é a de que a alma não foi feita para viver numa coisa, logo, "quando é constrangida a isso, tudo nela padece de violência" (WEIL, CO, 1996, p.381).

A ilustração para essa alma que padece de violência é o canto XXIV da Ilíada (um dos mais tocantes da epopeia de Homero), mais precisamente o encontro do velho Príamo com o algoz de seu fillho, o reluzente Aquiles (que matou não só Heitor, mas muitos filhos do rei de Tróia). Fiquemos com a narrativa weiliana:

Quando, fora de combate, um estrangeiro fraco e sem armas suplica a um guerreiro, não é condenado à morte por isso; mas um instante de impaciência por parte do guerreiro bastaria para tirar-lhe a vida. É o bastante para que sua carne perca a propriedade principal de carne viva. Um pedaço de carne viva manifesta a vida antes de mais nada pelo sobressalto; uma pata de rã, sob o choque elétrico, salta; o aspecto próximo ou o contato com uma coisa horrível ou terrível faz sobressaltar qualquer nó de carne, de nervos e de músculos. Só esse suplicante não estremece, não vibra, não tem mais licença; seus lábios vão tocar o objeto para ele mais carregado de horror... O espetáculo de um homem reduzido a esse grau de desgraça gela quase como gela o aspecto de um cadáver" (WEIL, CO, 1996, p.381-2).

Para Simone Weil, o fato de um pai ter que beijar a mão do assassino do seu filho é um exemplo por demais pungente de um ser humano transformado em coisa, de uma morte em vida que ela vê como uma contradição do ponto de vista lógico, mas, como ela afirma, quando o impossível se tornou uma realidade, a contradição se torna na alma dilaceramento e essa morte se estende ao longo de toda uma vida.

Numa guerra, para a pensadora em apreço, a força é o único herói, petrifica de formas diferentes, mas igualmente exerce o seu poder sobre quem a sofre e sobre quem a maneja. Só se escapa dela por uma espécie de milagre e os milagres são raros, como podemos ler quando ela aborda, também, o tema da compaixão para com os infelizes e afirma ser esta (a compaixão) uma impossibilidade. Reitera: "Quando ela se produz 
realmente, é um milagre mais surpreendente do que a caminhada sobre as águas, a cura dos doentes e mesmo a ressurreição de um morto" (WEIL, $A D, 2005$, p.110). Passemos, assim, da força à compaixão, sem sairmos, entretanto, do tema da miséria humana ${ }^{12}$.

\section{A MisÉria HUMANA À LUZ DA COMPAIXÃo}

Para abordarmos este tema, focaremos no escrito $O$ amor de Deus e a infelicidade que se encontra na obra Attende Dieu, embora outros escritos desta mesma obra e outros textos weilianos aqui compareçam. Desta forma, no Prefácio que Pe. Perrin faz àquele livro, ele diz que a compaixão pelos infelizes é uma marca dominante da vida de Simone Weil e acrescenta que para quem ama, verdadeiramente, como ela amou, a compaixão é um tormento. Mesmo assim, a compaixão weiliana é fruto de um ambiente cercado de amor como escreve o dominicano: "Para compreender o carácter extraordinário desta compaixão - e que se manteria um dos traços dominantes da sua vida - é preciso recordar o desafogo material, a abertura de espírito e o afeto com que os seus pais sempre a envolveram" (PERRIN, 2005, p.24).

$\mathrm{E}$ interessante observar que as condições materiais (econômicas e sociais) que cercaram o crescimento de Simone Weil, foram condições que lhe permitiram também, de alguma forma, o desenvolvimento da sua inteligência e do seu espírito para os invisíveis do mundo, quando ela tinha tudo e vivia um momento histórico em que poderia pensar somente em si mesma e nos seus mais próximos. Logo, quando uma outra Simone, a de Beauvoir, como já apontamos, define Simone Weil como um coração capaz de bater através do universo inteiro, não está exagerando, se levarmos em conta, para ficarmos com mais um exemplo, uma passagem de uma carta, com data incerta, mas do ano de 1942, uma vez que redigida em Nova York, endereçada ao seu amigo Maurice Schumann:

A dor e o perigo me são essenciais por causa da minha formação intelectual. É uma sorte que nem todo mundo a tenha, pois do contrário, qualquer ação organizada seria impossível, mas eu, eu não posso mudar; e o sei por uma vasta experiência. A infelicidade espalhada sobre a face do globo terrestre me obceca e me domina ao ponto de anular minhas faculdades, e eu não posso as recuperar e me livrar dessa obsessão se eu mesma não tiver uma parte importante neste perigo e neste sofrimento. É, pois, uma condição para eu ter a capacidade de trabalhar (WEIL, EL, 1957, p. 199) ${ }^{13}$.

Como vemos no excerto acima, a forma de filosofar da pensadora parisiense está intrinsecamente relacionada à sua forma de estar no mundo e dele participar, seja por meio da sua beleza ou da sua dor. Elementos igualmente indissociáveis quando se reflete, em profundidade, o seu conceito de malheur (infelicidade), afinal, como ela afirma em um passo de Attende Dieu: "Na beleza do mundo a necessidade bruta tornase objeto de amor" (WEIL, $A D, 2005$, p. 117). O Excerto encontra-se em $O$ amor de Deus e a infelicidade (o livro Attende Dieu é composto de vários textos e cartas) e quase na sequência da citação supra, ela escreve: "Todos os horrores que se produzem neste mundo são como as dobras que a gravidade imprime às vagas. É por isso que encerram uma beleza. Por vezes um poema, como a Ilíada, torna essa beleza sensível" (WEIL, $A D, 2005$, p. 117-118). Há outras passagens neste texto que, mesmo sem fazer referência à Ilíada, podem ser a ela relacionadas, pelo menos no que toca à leitura weiliana apresentada na parte anterior deste artigo. Esta leitura, por sua vez e na nossa interpretação, está associada à condição da miséria humana que não deixa de ter relação com o conceito de malheur, mas aqui não o refletiremos em todos os seus aspectos (incluindo a beleza e a dor que referenciamos mais acima), mas somente na sua relação com a compaixão ${ }^{14}$.

Continuemos com o escrito $O$ amor de Deus e a infelicidade. Logo no início 
deste texto nossa pensadora se esforça por esclarecer o que denomina de malheur (infelicidade) e começa por diferenciá-la do simples sofrimento físico, afirmando que o fator social é fundamental para se conceituar, na sua amplitude, a infelicidade, pois esta é um desenraizamento da vida e equivale, mais ou menos, à morte. Não àquela morte sumária que vimos no texto em que analisa a Ilíada, mas equivale àquela mais sutil, também já interpretada por ela no texto homérico, isto é, aquela capaz de transformar o homem em pedra ou coisa. Assim, semelhante à força que arrasta cegamente vencedores e vencidos, a infelicidade, no texto ora analisado, é antes de tudo, como nos diz Simone Weil, anônima e, assim, complementa: "[...] priva da sua personalidade aqueles de quem se apodera e faz deles coisas. É indiferente, e é o frio desta indiferença, um frio metálico, que gela até ao fundo da alma todos os que lhe tocam. [...] Jamais voltarão a acreditar que são alguém" (WEIL, $A D, 2005$, p. 114). Embora sejam dois conceitos diferentes, força e infelicidade se cruzam no anonimato da forma como atingem a todos e podem ser entendidos (ambos os conceitos) na definição de infelicidade que aparece em $O$ amor de Deus e a infelicidade como "[...] a pulverização da alma pela brutalidade mecânica das circunstâncias" (WEIL, AD, 2005, p. 136).

De qualquer forma, há algo que pode erguer as pessoas que estão submetidas a essa brutalidade e esse algo precioso é o amor. Deste modo, já em A Ilíada ou o poema da força é dito que uma alma só escapa à força por uma espécie de milagre e que há momentos luminosos na epopeia que nossa pensadora chama de "breves momentos divinos durante os quais os homens têm uma alma" e acrescenta: "Os outros momentos durante os quais os homens encontram a sua alma são os do amor; quase nenhuma forma pura de amor entre os homens está ausente na Ilíada" (WEIL, CO, 1996, p.399). Esta forma pura de amor em $O$ amor de Deus e a infelicidade é o amor sobrenatural ${ }^{15}$ que permite, como veremos, falar da compaixão. Mas, antes, tentemos compreender, minimamente, esse amor. Em um passo primoroso deste escrito, que filia, com todas as credenciais que tem direito, Simone Weil à mística, lemos:

A infinidade do espaço e do tempo separam-nos de Deus. Como poderíamos nós procurá-lo? Como poderíamos ir na sua direção? Mesmo que caminhássemos ao longo de todos os séculos, mais não faríamos do que andar à volta da terra. Mesmo de avião, não poderíamos fazer outra coisa. Estamos excluídos da possibilidade de avançar verticalmente. Não podemos dar um passo em direção aos céus. Deus atravessa o universo e vem até nós. Por cima da infinidade do espaço e do tempo, o amor infinitamente mais infinito de Deus vem resgatar-nos. Vem à sua hora. Nós temos o poder de consentir em acolhê-lo ou de recusar. Se permanecemos surdos, ele regressa e volta a regressar ainda, como um mendigo, mas, também como um mendigo, um dia não regressa mais. Se consentimos, Deus coloca em nós uma pequena semente e parte. A partir desse momento, Deus nada mais tem a fazer senão esperar, e nós tão pouco. Nós devemos apenas não lamentar o consentimento que demos, o sim nupcial. Isto não é tão fácil como parece, porque o crescimento da semente em nós é doloroso (WEIL, $A D, 2005$, p. 121).

A verticalidade é o caminho da metafísica tradicional e não da mística, assim como o apofântico é a linguagem daquela em detrimento do predomínio da linguagem apofática da mística que culmina em a Teologia mística do pseudo-Dionísio no silêncio hierofânico e, nesta parte do escrito weiliano, no consentimento acolhedor e silencioso do qual só resta, depois, esperar. $\mathrm{O}$ que nos faz lembrar do conceito de gelassenheit eckhartiano ${ }^{16}$, atestando, assim, que na segunda fase da sua filosofia, a pensadora em apreço, realmente, para além da retomada da filosofia grega antiga, vai se dedicar também aos autores místicos. Mas voltemos ao amor. Depois de colocada as condições para o consentimento do amor sobrenatural, Simone Weil nos esclarece que o amor não é um estado de alma, mas uma orientação, e adverte: "Se o ignoramos caímos no desespero ao primeiro golpe da infelicidade" (WEIL, $A D, 2005$, p. 123). Pensamos que 
a mesma frase pode ser repetida quando se trata da força e esse amor, esta orientação, implica na negação do nosso eu, como ela escreve: "Nós podemos apenas consentir em perder os nossos sentimentos próprios para abrir passagem na nossa alma a esse amor. É isso negar-se a si mesmo. Não somos criados senão para este consentimento" (WEIL, $A D, 2005$, p. 122).

A negação do eu é outro aspecto importante da mística, de uma forma geral. Neste sentindo, como já procuramos mostrar em um outro estudo, o conceito de descriação weiliano se aproxima do conceito de aniquilamento poretiano ${ }^{17}$. Mas o que significa essa negação de si, posta por Simone Weil? Bem, ela vai dizer que a nossa carne é fraca, nossa alma é vulnerável e nossa pessoa social está constantemente exposta aos acasos, isto é, o que cremos ser o nosso eu, segundo Weil, nada mais é do que "[...] um produto tão fugidio e tão automático das circunstâncias exteriores como a forma de uma ondulação marítima", por fim, negar-se a si mesmo é "[...] confessar que se é apenas um fragmento da matéria inerte que compõe a criação" (WEIL, $A D, 2005$, p. 131).

A infelicidade que, como já chamamos atenção, é muito mais do que um simples sofrimento físico ${ }^{18}$, termina por fazer, quando consentimos, que reconheçamos a miséria humana e nos reconheçamos como um fragmento que compõe a beleza da criação. Assim, reconhecer-se, por sua vez, implica em dizer que uma inteligência iluminada pelo amor nega o seu eu, por ser, dentre outras coisas, medíocre - pois como escreve Weil, em que é que uma vida medíocre é superior à infelicidade? - e, ao negálo, abre-se para o amor sobrenatural que nos permite o milagre da compaixão que se dirige sempre para o outro, já que, para a filósofa francesa, não temos o direito de sentir compaixão por nós próprios, visto que há coisas tão atrozes "nas nossas instituições e nos nossos costumes que ninguém pode legitimamente julgar-se absolvido desta cumplicidade difusa. Decerto que cada um se tornou culpado pelo menos de indiferença criminosa" (WEIL, $A D, 2005$, p. 125).

E ela segue com esse raciocínio de não devermos ter compaixão por nós próprios lembrando da infelicidade (que incluiu também a injustiça) sofrida por Cristo, e aproveita para falar do sentido da sua cruz que, para ela, não significa, por uso abusivo da linguagem, simplesmente resignar-se aos pequenos problemas ou aborrecimentos cotidianos, pois, "Carregar a sua cruz é carregar o conhecimento de que estamos inteiramente submetidos a esta necessidade cega [...]". Continua, num tom ainda mais cortante, porque não dizer, trágico (referindo-se ao modelo de ser humano adotado): "Um homem perfeitamente feliz pode ao mesmo tempo gozar plenamente a alegria e carregar a sua cruz se tem realmente, concretamente e em todos os momentos o conhecimento da possibilidade da infelicidade" (WEIL, $A D, 2005$, p. 127). Ou seja, para a pensadora em apreço, importa, como lemos em La connaisance surnaturelle, o modo como concebemos a nossa vida aqui na terra, quer dizer, sempre prontos a reconhecer, portanto, lúcidos, mesmo quando estamos bem, de que podemos, a qualquer momento, ser subjugados pelas forças cegas da necessidade e, assim, não se trata de resignação, mas de como se encara ou se enfrenta o nosso modo de estar no mundo. Esta forma de pensar aproxima Simone Weil dos trágicos, como tão bem nos mostra Fernando Puente ao aproximá-la de Nietzsche e da Grécia ${ }^{19}$ :

[...]o que há de comum é que tanto um quanto o outro alicerçaram as suas teses em uma determinada reconstrução filosófica da Grécia. [...] os dois acreditaram poder reconstituir a verdadeira e autêntica Grécia, soterrada, segundo Nietzsche, pelos escombros de uma erudição mórbida, incapaz de apreender a irrupção espontânea e transbordante de vida do fenômeno dionisíaco; ou, segundo Simone Weil, adulterada e incompreendida pela ausência de um real entendimento da espiritualidade específica do mundo helênico. O modelo de homem proposto por esses dois pensadores poderia ser definido, em linhas gerais, como um modelo trágico do homem (PUENTE, 2013, p. 36) 
Destarte, podemos dizer que na cultura grega clássica Simone Weil redescobre, no sentido em que para ela sempre lá esteve presente, uma espiritualidade inseparável da ideia de trágico que vai ser lida, por sua vez, à luz da miséria humana expressa pelo conceito de infelicidade ou de força que necessita, por seu turno, da compaixão, para que o ser humano não seja transformado pela força que não mata (ainda), ou seja, naquela que o transforma em pedra (como vimos na leitura weiliana da Ilíada) ou o leve a se entregar à gravidade (como podemos ler no texto $O$ amor de Deus e a infelicidade), o que dá no mesmo. Neste sentido, se a infelicidade priva aquele que sofre de existir, pois ele se torna uma coisa ou um verme, compadecer-se deste infeliz é, segundo nossa pensadora, transportar o nosso próprio ser para ele, dando-lhe um instante de existência. Ela compara o infeliz com Cristo e diz que este esvaziou-se da sua divindade por amor, enquanto o infeliz é esvaziado da sua humanidade pela má sorte que sofreu. Deste modo, a espiritualidade aqui pensada deve reverberar no mundo, como Simone Weil escreve (a citação é um pouco longa, mas pensamos valer a pena):

Aquele que, ao ver um infeliz, transporta até ele o seu ser, faz nascer nele por amor, ao menos por um momento, uma existência independente da infelicidade. Porque apesar de a infelicidade ser ocasião desta operação sobrenatural, não é a sua causa. A causa é a identidade dos seres humanos através de todas as distâncias aparentes que entre eles põe o acaso da sorte. Transportar o seu ser até um infeliz é assumir a sua infelicidade por um momento, tomar voluntariamente aquilo cuja própria essência consiste em ser imposta à força e contra a vontade. Encontra-se aí uma impossibilidade. Apenas Cristo o fez. Apenas Cristo pode fazê-lo, e os homens nos quais Cristo ocupa toda a alma. Esses, ao transportarem o seu próprio ser até ao infeliz que socorrem, introduzem nele, de facto, não o seu próprio ser, porque não o têm mais, mas Cristo ele mesmo. A esmola assim praticada é um sacramento, uma operação sobrenatural pela qual um homem habitado por Cristo introduz realmente Cristo na alma de um infeliz (WEIL, $A D$, 2005, p. 134).

Naturalmente que a citação por si só daria um artigo. Então, fiquemos apenas com alguns aspectos, os que nos chamam atenção para o tema aqui abordado. Primeiro, a relação infelicidade-ocasião, isto é, ninguém deseja a infelicidade, mas há ocasiões em que independente da nossa vontade ela ocorre. É, portanto, algo que nos é externo e que só nos cabe enfrentar com galhardia. É, falando com o rigor do termo, o que ela chama de amor fati e que não vamos abordar aqui ${ }^{20}$. Fiquemos com esta disposição da alma para agirmos como um ser que pensa e sente e que, deste modo, em nada se assemelha a uma pedra ou a um verme meio esmagado que se agita ao sol. Segundo, pensemos a relação entre causa e identidade. Simone Weil afirma que a infelicidade é apenas a ocasião para realização de socorro aos infelizes, a causa mesmo é o fato de sermos humanos (nossa identidade), mesmo com todas as diferenças que nos constituem porque a aparente distância entre o acaso e a sorte desaparece por meio da luz do amor sobrenatural. Terceiro, assumir a infelicidade do outro é uma impossibilidade e uma impossibilidade só pode ser contornada por meio de um milagre e este acontece quando negamos o nosso eu (egóico) e abrimos, com isso, um espaço para que Cristo habite em nós.

A habitação de Cristo em nós, entretanto, está para além do plano meramente religioso, no sentido da igreja enquanto coisa social ${ }^{21}$. O pensamento religioso weiliano ultrapassa em muito a ideia de aceitar e seguir determinados preceitos. Está enraizado numa espiritualidade pensada e vivida em favor de todos os oprimidos do mundo, por conseguinte, ela sabe que em todas as diferentes correntes religiosas, que estudou e conheceu, é possível encontrar ensinamentos que aproximem os seres humanos uns dos outros, sobretudo, ensinamentos que os conduzam a diminuir a dor daqueles a quem o acaso, pela força ou pela infelicidade, fez deles suas vítimas. Por isso, talvez, ela escreva: "[...] um Estado não tem o direito de se separar de toda a religião, a não ser na hipótese absurda em que tivesse alcançado suprimir a infelicidade. Por maioria de 
razão, não tem esse direito quando fabrica ele próprio infelizes"22 (WEIL, $A D, 2005$, p. 139). É com esta lucidez que ela assevera que os infelizes precisam de pessoas que lhes prestem atenção, embora reconheça que esta capacidade, a de prestar atenção a um infeliz, seja algo muito raro. De fato, um verdadeiro milagre. Por conseguinte, de forma tocante, nos interpela no texto Reflexões sobre o bom uso dos estudos escolares em vista do Amor de Deus:

A plenitude do amor ao próximo é simplesmente ser capaz de lhe perguntar: «Qual é o teu tormento?» É saber que o infeliz existe, não como unidade numa colecção, não como um exemplar da categoria social etiquetada «infelizes», mas enquanto homem exatamente semelhante a nós, que foi um dia atingido e marcado com uma marca inimitável pela infelicidade. Para isso é suficiente, mas indispensável, saber pousar sobre ele um certo olhar. Este olhar é em primeiro lugar um olhar atento, em que a alma se esvazia de todo o conteúdo próprio para receber nela mesma o ser que olha como ele é, em toda a sua verdade (WEIL, $A D$, 2005, p. 105-106).

Embora com outras palavras e num texto que tem como foco um conceito que lhe é caro e que não abordamos aqui, o conceito de atenção, a citação supra fala também, como a citação da página 134 do texto $O$ amor de Deus e a infelicidade - que fizemos um pouco mais acima - sobre a infelicidade, sobre a nossa humanidade, sobre o amor, sobre o esvaziamento do nosso eu e da nossa capacidade de nos inclinarmos para o outro que sofre, não por força das necessidades mecânicas, mas porque consentimos numa operação sobrenatural. Neste sentido, entendemos que a compaixão é o milagre operado pelo amor sobrenatural, no qual a presença divina se realiza em todos os miseráveis do mundo que recebem esse olhar amoroso. Quando não somos capazes deste olhar, os infelizes somos nós com os nossos apegos e com a ilusão da nossa vida medíocre e, deste modo, a infelicidade atinge a todos, assim como a força faz perecer vencedores e vencidos.

\section{Simone WeIL E A MISÉRIA de SUA VOCAÇÃo INTELECTUAL}

Retomemos, com o objetivo de finalizar este artigo, um tema posto nas nossas Considerações iniciais e que diz respeito à vocação intelectual de Simone Weil. Em diversas partes dos escritos weilianos encontramos referências à esta vocação que, entretanto, ao contrário do que se poderia pensar numa primeira leitura, une trabalho intelectual e braçal, inteligência e espiritualidade. Destarte, podemos ler em algumas passagens de uma carta enviada aos seus pais, em julho de 1943, onde, se referindo a uma pessoa querida de inicial M, afirma que esta pessoa acredita que ela (Simone Weil) tem alguma coisa para oferecer. Apesar de não achar a ideia bem formulada, a nossa pensadora diz ter a certeza de que nela se encontra um depósito de ouro puro que deve ser transmitido, mesmo observando, quando olha para os seus contemporâneos, que não há ninguém para recebê-lo (Cf. WEIL, EL, 1957, p. 250). Ela já havia afirmado numa carta anterior a esta (de maio do mesmo ano) que a mina de ouro era inesgotável, no entanto, consciente da sua vocação intelectual, assevera: "[...] eu não penso ter o menor motivo para supor que o que escrevo deva ter um dia alguma eficácia...Como você deve saber, mas isso não me impede de escrever" (Cf. WEIL, EL, 1957, p. 237).

Ora, sua vocação intelectual lhe impele ao exercício da escrita, mas esta, por seu turno, não está dissociada da ideia de que o trabalho intelectual traz responsabilidades terríveis, como ela afirma numa carta que envia a Gustave Thibon, antes de fazer a experiência de trabalhar no campo, como podemos ler: "Eu penso que a cultura intelectual, longe de dar direito a privilégios, constitui, em si mesma, um privilégio que é quase assustador e que envolve, em contrapartida, responsabilidades terríveis...[...]" (WEIL apud THIBON, 2003, p. 103). Para ela, o intelectual, mais do que nenhum 
outro, exatamente porque tem um maior conhecimento e esclarecimento do que ocorre no mundo, tem responsabilidades que ela considera terríveis e, por isso, no mínimo, deve ser responsável quando escreve, pois sabe do poder que as palavras desempenham. Mas o mínimo, para a escritora francesa, nunca parece suficiente, porque ela é uma dessas inteligências iluminadas pelo amor sobrenatural. Por isso, sua vocação exigia mais, exigia, como ela escreve numa carta que envia ao Pe. Perrin, datada em 19 de janeiro de 1942, ir ao encontro dos menos favorecidos:

Possuo a necessidade essencial, e creio poder dizer a vocação, de passar por entre os homens e atravessar os diferentes meios humanos confundindo-me com eles, adotando a mesma cor na máxima medida admissível pela consciência, desaparecendo no seu seio, isto para que se mostrem tal como são e sem disfarce para mim. É que desejo conhecê-los a fim de os amar tal como são. Porque se não os amo tal como são, não é a eles que amo e o meu amor não é verdadeiro (WEIL, $A D, 2005$, p. 39).

Consciente do poder da sua escrita e da sua vocação intelectual, Simone Weil nos mostra que o trabalho intelectual pode ir além dos gabinetes, nos mostrando, também, que é preciso amar as pessoas como elas são para que este amor não seja uma projeção do nosso amor narcísico, mas um amor puro, isto é, sobrenatural, que ocorre no movimento da compaixão. Movimento proporcionado pela miséria humana que, todavia, mesmo iluminado pelo consentimento ao amor sobrenatural, está muito além de qualquer denominação religiosa, pois se encontra enraizado numa espiritualidade bastante desenvolvida. Não é à toa que Simone Weil em muitos passos dos seus escritos fala de probidade intelectual. Escreve, por exemplo, no texto que tem como título $A$ sua vocação intelectual, que pela força da sua vocação pessoal, o seu grau de probidade intelectual que lhe é obrigatório, "exige que o meu pensamento seja indiferente a todas as ideias sem exceção, incluindo, por exemplo, o materialismo e o ateísmo; igualmente acolhedor e reservado em relação a todos" (WEIL, $A D, 2005$, p. 78).

Ora, o que pensar de uma filosofia feita com toda a intensidade dos afetos e com toda a lucidez do intelecto, cujo vigor, no cruzamento da inteligência com o amor, nos conduz ao encontro, no mínimo, da reflexão da miséria humana quando a espiritualidade passa a ser mais do que um objeto de estudo da filosofia, passa a ser um componente importante deste saber. Sendo assim, quando procuramos, ao longo deste texto, mostrar os conceitos de força e de infelicidade e suas implicações, esperávamos que as relações entre filosofia e espiritualidade fossem refletidas, de alguma forma. Talvez essas relações fiquem mais claras quando - parafraseando as últimas palavras de A Ilíada ou o poema da força - deixarmos de admirar a força, de odiar os inimigos e de desprezar os infelizes. Mas, assim como Simone Weil, duvidamos que seja para já.

\section{REFERÊNCIAS}

BEAUVOIR, S. Memórias de uma moça bem-comportada. 2. ed. Trad. Sérgio Milliet. Rio de Janeiro: Nova Fronteira, 2009.

BINGEMER, M. C. Simone Weil: a força e a fraqueza do amor. Rio de janeiro: Rocco, 2007.

ESTELRICH, B. Filosofia como exercício espiritual: Simone Weil e Pierre Hadot. In: BINGEMER, M. C (Org.). Simone Weil e o encontro entre as culturas. Rio de Janeiro: Ed. PUC/Rio e Paulinas, 2009, p. 39-57.

NOGUEIRA, M. S. M. Aniquilamento e descriação: uma aproximação entre Marguerite Porete e Simone Weil. Revista Trans/Form/Ação, Marília, v. 42, n. 4, p. 193-216, 2019, Edição Especial.

NOGUEIRA, M. S. M. A filosofia de Simone Weil: uma mística da ação e da contemplação. Revista Sísifo, Feira de Santana, v. 1, n. 6, p. 1-11, 2017.

NOGUEIRA, M. S. M. Plotino e Mestre Eckhart: uma mística da unidade. Revista Ágora 
filosófica, Recife, v. 1/2, p. 103-115, 2003.

PERRIN, J. -M. Prefácio de $A$ espera de Deus. Tradução: Manuel Barreiros. Lisboa: Assírio e Alvim, 2005, p. 23-31 (Coleção Teofanias).

PUENTE, F. R. Exercícios de atenção. Simone Weil. Leitora dos gregos. Rio de Janeiro: Editora PUC/RJ e São Paulo: Loyola, 2013.

158 SILVA, M. Simone Weil. "Actualidade de uma estranha mística para os nossos estranhos tempos". Disponível em: <http://www.fundacao-betania.org /biblioteca/ profetas/ Simone_Weil.pdf $>$. Acesso em: 08 mai. 2017.

THIBON, G; PĒRRIN J. M. Simone Weil as we knew her. Trad. Emma Craufurd. London; New York: Routledge; Taylor \& Francis Group, 2003.

VERNANT, J. -P. A bela morte e o cadáver ultrajado. Trad. Elisa A. Kossovitch e João. A. Hansen. Revista Discurso, São Paulo, n. 9, 1978, p. 31-62.

WEIL, S. Carta a Georges Bernanos. In: BINGEMER, M. C. Simone Weil: a força e a fraqueza do amor. Rio de janeiro: Rocco, 2007, p.291-296.

WEIL, S. La connaissance surnaturalle. Paris: Éditions Gallimard, 1950 (Collection Espoir).

WEIL, S. A gravidade e a graça. Tradução: Paulo Neves. São Paulo: Martins Fontes, 1993. (Coleção Tópicos).

WEIL, S. A espera de Deus. Tradução: Manuel Barreiros. Lisboa: Assírio e Alvim, 2005 (Coleção Teofanias).

WEIL, S. Écrits historiques et politiques. Paris: Éditions Gallimard, 1960. Partie I e II - Histoire et Politique, (Collection Espoir).

WEIL, S. Lettres à Maurice Schumann. In: Écrits de Londres et dernières lettres. Paris: Éditions Gallimard, 1957, p. 185-215 (Collection Espoir).

WEIL, S. Antígona. In: BOSI, E. (Org.). A condição operária e outros estudos sobre a opressão. 2. ed. rev., trad. de Therezinha Langlada. Rio de janeiro: Paz e Terra, 1996, p. 373-378.

WEIL, S. A agonia de uma civilização vista através de um poema épico. In: BOSI, E. (Org.). A condição operária e outros estudos sobre a opressão. 2. ed. rev., trad. de Therezinha Langlada. Rio de janeiro: Paz e Terra, 1996, p. 267-277.

WEIL, S. A Ilíada ou o poema da força. In: BOSI, E. (Org.). A condição operária e outros estudos sobre a opressão. 2. ed. rev., trad. de Therezinha Langlada. Rio de janeiro: Paz e Terra, 1996, p. 379-407.

WEIL, S. Sur la science. Paris: Éditions Gallimard, 1966 (Collection Espoir).

\section{Notas}

1 Sobre o Pe. Perrin, veja-se nosso artigo, NOGUEIRA, 2017, A filosofia de Simone Weil: uma mística da ação e da contemplação, nota 20, p. 9.

2 Attende Dieu, doravante referenciado por $A D$, embora estejamos utilizando a edição portuguesa (Espera de Deus, 2005).

3 Embora entenda, do ponto de vista do gênero literário, a Ilíada como uma epopeia, não a interpreta, necessariamente, como a narrativa dos feitos de um grande herói e assim a ela se refere num texto de 1942 que se encontra nos seus Ecrits historiques et politiques, doravante citado por EHP: "Comparando à Ilíada as epopeias medievais em língua francesa, sente-se vivamente que as façanhas, os sofrimentos, a morte de alguns guerreiros parecem, no plano épico, coisas pequenas e frias. Toda uma civilização, outrora florescente, de repente, destruída pelo golpe mortal da violência das armas, destinada a desaparecer sem retorno possível e representada nas últimas palpitações da agonia: esse é, talvez, o único tema bastante grande para a epopeia. É o da Ilíada; [...]”. (WEIL, EHP, 1996, p. 267, usamos aqui a tradução portuguesa, A agonia de uma civilização vista através de um poema épico, que se encontra em BOSI, 1996, p. 267-277).

4 Nestes três últimos parágrafos retomamos, com algumas modificações e pequenos acréscimos, parte do nosso estudo já citado, NOGUEIRA, 2017. Para o contexto completo da citação de Simone de Beauvoir remetemos a outro estudo nosso, NOGUEIRA, 2019, Aniquilamento e descriação: uma aproximação entre Marguerite Porete e Simone Weil, 
nota 18, p. 204.

5 La Pensateur et la grâce, doravante referenciado por $P G$, embora estejamos utilizando a edição portuguesa (A gravidade e a graça, 1993).

6 Quando termina a Primeira Guerra Mundial, Simone Weil tem nove anos de idade e quando começa a Segunda Guerra Mundial, ela tem trinta anos. Neste ínterim, experimentou muita coisa, como podemos ler nesta passagem de uma carta endereçada ao escritor do livro Les grands cimetières sous la lune, George Bernanos, que se encontra em BINGEMER, 2007, p. 294-295: "O essencial é a atitude com relação ao assassinato. Eu nunca vi, nem entre os espanhóis, nem mesmo entre os franceses vindos seja para combater, seja para passear [...], nunca vi ninguém expressar, mesmo na intimidade, repulsa, desgosto ou somente desaprovação com relação ao sangue inutilmente derramado. Homens aparentemente corajosos [...], no meio de uma refeição cheia de companheirismo, contavam com um bom sorriso fraterno como eles haviam matado padres ou "fascistas" [...]. Tive o sentimento, para mim, que quando as autoridades temporais e espirituais colocaram uma categoria de seres humanos fora daqueles cuja vida tem um preço, não há nada mais natural para o homem que matar".

7 Doravante identificado por $S G, L a$ source grecque, embora estejamos utilizando a tradução brasileira organizada por Ecléa Bosi.

8 Seguimos com os textos organizados por Ecléa Bosi, 1996, mas a carta supra citada encontra-se em La condition ouvrière, daí as letras $C O$, na referência acima.

9 Lembramos aqui do belíssimo texto de VERNANT, 1978, A bela morte e o cadáver ultrajado.

10 A força, conforme (BINGEMER, 2007, p. 99), embora possa ser equivalente à violência, sobretudo quando Weil se refere aos conflitos armados, não tem apenas este sentido, isto é: "Impõe-se reconhecer que o conceito de "força" é mais freqüentemente encontrado em seu pensamento, sendo mesmo perceptível uma originalidade na maneira como o emprega: ou seja, como uma chave de leitura fundamental para entender as relações humanas e sociais". Outra leitura muito interessante sobre o mesmo tema nos oferece, PUENTE, 2013, p. 69-77, quando, num capítulo do seu livro dedicado a Simone Weil, reflete sobre a Antiguidade como modelo de leitura da força na filosofia weiliana.

$11 \mathrm{Na}$ primeira citação da Ilíada que aparece no texto weiliano há uma nota com o seguinte conteúdo: "A tradução das passagens é nova. Cada linha traduz um verso grego, reproduzindo-se escrupulosamente os encadeamentos; a ordem das palavras gregas no interior de cada verso é respeitada tanto quanto possível. (Nota de S. Weil)" (WEIL, CO, 1996, p. 379, nota *).

12 Como a nossa intenção não era, necessariamente, aprofundar o estudo sobre o tema da força em Simone Weil, indicamos, para quem quiser ter uma leitura mais ampla sobre isso, além do texto A Ilíada ou o poema da força, também, Reflexões sobre a guerra (ambos com tradução para o português no livro organizado por Ecléa Bosi, 1996). Ademais, são importantes também os seguintes textos: Réflexions sur la barbárie, Réflexions sur la guerre, Réflexions en vue d'un bilan, Ne recommençons pas la guerre de Troie. Estes se encontram nos Écrits historiques et politiques, 1960, nas duas partes em que estão divididos.

13 Esta e outras cartas dirigidas a Maurice Schumann encontram-se no livro Écrits de Londres et dernières lettres, identificado pelas letras $E L$.

$14 \mathrm{O}$ conceito de malheur de Simone Weil é por demais complexo não só pelas contradições que ele abarca como também por outros conceitos que nele estão incluídos como beleza, dor, compaixão, justiça, amor, finito, infinito e a cruz de Cristo, para citarmos alguns.

15 Embora Simone Weil não fale de amor sobrenatural quando faz a sua leitura da Ilíada, é disto que se trata quando se refere à forma pura de amor, como podemos ver num outro texto seu: "Não se pode perceber a presença de Deus num homem, mas somente o reflexo desta luz na forma como ele concebe a vida terrestre. Assim, o verdadeiro Deus está presente na Ilíada [...]". E mais adiante: "Ilíada: somente o amor de Deus pode permitir a uma alma discernir tão lucidamente, tão friamente o horror da miséria humana sem perder nem a ternura nem a serenidade" (WEIL, CS, 1950, p. 95 e 97, respectivamente). A citação encontra-se no livro La connaissance surnaturelle, daí a indicação CS. 
16 Para uma aproximação da gelassenheit de Eckhart com a mística de Plotino, veja-se nosso estudo, NOGUEIRA, 2003, Plotino e Mestre Eckhart: uma mística da unidade.

17 Abordamos isso no nosso artigo, NOGUEIRA, 2019, já citado.

18 Uma outra definição importante de infelicidade (malheur) pode ser vista na p. 108 de $O$ amor de Deus e a infelicidade: "Só há verdadeiramente infelicidade quando o acontecimento que colheu uma vida e a desenraizou a atinge, direta ou indiretamente, em todas as suas partes, sociais, psicológicas, físicas. $\mathrm{O}$ fator social é essencial. Não há verdadeiramente infelicidade onde não há, de alguma forma, degradação social ou a angústia de uma tal degradação".

19 Sabemos que Simone Weil não gostava nem um pouco de Nietzsche. Chega mesmo a dizer, numa carta que envia ao seu irmão, André Weil, e que se encontra no livro Sur la science (doravante identificado SS) que o considera intolerável ("Même quand il exprime des choses que je pense, il m'est littéralement intolérable". WEIL, SS, 1960, p.163). Puente também sabe disso e por isso chama a atenção dos seus leitores: "Todavia, cabe-nos advertir o leitor, desde já, da distância quase intransponível que separa o conceito de trágico em Nietzsche do seu correlato em Simone Weil. Desse modo, através de uma investigação que procederá procurando estabelecer a cada passo a oposição diametral entre essas duas filosofias, esperamos poder ganhar alguma nova compreensão sobre dois pensadores que propõem dois modelos de vida alternativos (ancorados em uma determinada reconstrução filosófica da Grécia) para os dilemas que, ainda hoje, acometem a nossa civilização. Interessa-nos também, em particular, recuperar a dimensão autenticamente filosófica da obra de Simone Weil e retirá-la do imerecido esquecimento em que se encontra em nosso meio acadêmico" (PUENTE, 2013, p. 36). Mostra, assim, com rigor, em que aspectos os dois se aproximam e se afastam no seu cap. Simone Weil, Friedrich Nietzsche e a Grécia, que se encontra na obra já citada, 2013, p. 33-68. Aliás, todo o livro de Puente é dedicado, com brilhantismo, à leitura de Simone Weil dos gregos

20 A noção de amor fati aparece várias vezes na sua obra, fiquemos, apenas para ilustrar, com esta passagem de La connaissance surnaturelle: "A aceitação do tempo e de tudo que ele pode trazer - sem exceção - (amor fati) - é a única disposição da alma que é incondicionada em relação ao tempo. Ela envolve o infinito. Aconteça o que acontecer... Deus deu às criaturas finitas este poder de se transportar no infinito. A matemática é uma imagem disso" (WEIL, CS, 1950, p. 92).

21 Sobre este tema, a igreja como coisa social, veja-se os quatro primeiros escritos da obra Attende Dieu (A Espera de Deus). Respectivamente as quatro primeiras cartas: Hesitações acerca do baptismo, Sobre o mesmo assunto, A propósito de sua partida e Autobiografia espiritual. Na primeira delas, ela escreve dando sinais do seu amor aos menos favorecidos que sempre marcou a sua trajetória filosófica: "Não posso deixar de me perguntar se, neste tempo em que tão grande parcela da humanidade se encontra submergida por materialismo, Deus não quer que haja homens e mulheres que se lhe dediquem e a Cristo e que, no entanto, permaneçam fora da Igreja. De todo o modo, quando antevejo, em concreto, e como uma coisa que poderia estar próxima, o ato pelo qual entraria na Igreja, nenhum pensamento me causa maior pesar que o da minha separação da massa imensa e infeliz dos descrentes" (WEIL, $A D, 2005$, p. 39).

22 Os infelizes para Simone Weil, como já mostramos, são todos aqueles que passam por uma degradação física, psicológica e social, mas num dado passo do seu texto, ela chega mesmo a ilustrar alguns destes quando afirma: "Ele é, conforme os casos, um pobre, um refugiado, um negro, um doente, um condenado, ou qualquer outra coisa desse gênero" (WEIL, $A D, 2005$, p. 133). Reforça, assim, como lemos no final da citação, a ideia do ser humano transformado em coisa, daí, marcado pela infelicidade. 